\title{
INNOVATION AND ENTREPRENEURSHIP INTEGRATION IN EDUCATION. OHAIO STATE MODEL
}

\section{MUNA ALJOHANI}

\begin{abstract}
:
Success in our global, collective future will depend on the students of today using 21st century skills to develop innovative solutions to key societal issues. Entrepreneurs, in turn, are individuals who transform these innovations into economic goods using financial and business acumen. In the long-term, the economic health of every region depends to some degree on what it does to help these individuals succeed.

Entrepreneurship drives economic change and innovation while at the same time expanding opportunity and unleashing the initiative of citizens. Entrepreneurs are crucial to building prosperous societies that deliver opportunity to all. In emerging economies around the world, interest in entrepreneurship is currently higher than ever amid burgeoning youth populations and a desire to move up value chains. The empowered citizen of the 21st century not only knows how to use technology, shelhe knows how to use technology to turn innovation into services, goods, or efficiencies that contribute to the local and regional economies, and perhaps most importantly the economy of herlhis own home.
\end{abstract}

Entrepreneurship education delivered on a foundation of 21st century skills, both within educational institutions and as a key element of lifelong learning, is necessary to drive innovation and therefore the economic health of any region. Unfortunately, in many developing economies, obstacles in the business environment close off entrepreneurial opportunities to huge swathes of the population, this paper will try to show the importance of innovation and entrepreneurship in modern education and societies and will try to answer the following questions:

1-what is the definition of entrepreneurship and innovation?.

2-what are the 21 st century learning, innovation, and career skills ?.

3-what is the importance of innovation and entrepreneurship in education?

4-what are the content standards for entrepreneurship education?

\section{Keywords:}

Education ,Innovation , Entrepreneurship

JEL Classification: $A 20, A 00$

\section{Authors:}

MUNA ALJOHANI, University of Tabuk, Saudi Arabia, Email: d.mona2010aljohani@gmail.com

\section{Citation:}


MUNA ALJOHANI (2015). Innovation and Entrepreneurship Integration in Education. Ohaio state model. International Journal of Teaching and Education, Vol. III(3), pp. 1-20.,

10.20472/TE.2015.3.3.001 


\section{Introduction:}

Success in our global, collective future will depend on the students of today using 21st century skills to develop innovative solutions to key societal issues Entrepreneurs, in turn, are individuals who transform these innovations into economic goods using financial and business acumen. In the long-term, the economic health of every region depends to some degree on what it does to help these individuals succeed Success in our global, collective future will depend on the students of today using $21^{\text {st }}$ century skills to develop innovative solutions to key societal issues Entrepreneurs, in turn, are individuals who transform these innovations into economic goods using financial and business acumen. In the longterm, the economic health of every region depends to some degree on what it does to help these individuals succeed.

Entrepreneurship drives economic change and innovation while at the same time expanding opportunity and unleashing the initiative of citizens. Entrepreneurs are crucial to building prosperous societies that deliver opportunity to all .The empowered citizen of the 21st century not only knows how to use technology, shelhe knows how to use technology to turn innovation into services, goods, or efficiencies that contribute to the local and regional economies, and perhaps most importantly the economy of her $\backslash$ his own home. In emerging economies around the world, interest in entrepreneurship is currently higher than ever amid burgeoning youth populations and a desire to move up value chains..Entrepreneurship education delivered on a foundation of 21 st century skills, both within educational institutions and as a key element of lifelong learning, is necessary to drive innovation and therefore the economic health of any region.

\section{Aims of the study:}

The aims of this study are:

1-to clarify the definitional issues related to the concept of innovation and entrepreneurship.

2-to clarify the 21 st century learning, innovation, and career skills.

3-to try to direct the educators to the links that can be made between educational goals ,learning skills, and career skills .

4-to illustrate the importance of innovation and entrepreneurship in education and for our countries development.

5-to give some suggestions about the best ways of integrating the practices of innovation and entrepreneurship in our educational system and,

6-to shed the light on international best practices in innovation and entrepreneurship integration in education (OHAIO MODEL )

\section{Questions of the study:}


1-How innovation and entrepreneurship are defined ?.

2-what are the 21 st century learning ,innovation , and career skills ?.

3-what is the importance of innovation and entrepreneurship in education?

4-what are the content standards for entrepreneurship education?

Method:

The researcher followed the descriptive method to collect the information related to this study .

\section{Theoretical background:}

\section{Innovation \& Interprunership, Definitional issues:}

Albert Einstein once said, "if I had 20 days to solve a problem, I would spend 19 days to define it." Good advice Innovation is everywhere From the advertisements on TV to the design of the iPod in your pocket

to the social services delivered on the streets of Delhi,

people and organizations are always creating new ideas, services, and products and adapting old ones to fit their changing circumstances ,

people and organizations are always creating new ideas, services, and products and adapting old ones to fit their changing circumstances.

Innovation has been and continues to be an important topic of study for a

number of different disciplines:

including economics,

business, engineering,

science, and sociology.

Despite the fact that innovation has been studied in a variety of disciplines, the term is often poorly understood and can be sometimes confused with related terms such as change, invention, design, and creativity.

Most people can provide examples of innovative products such as the iPod or the PC, but few can clearly define the innovative aspects of these products. Among academics there is a difference of opinion about what the term innovation really means.

One definition of innovation taken from the dictionary that fits the ideas and concepts used in this book is the following (The New Oxford Dictionary of English, 1998, p. 942):

"Making changes to something established by introducing something new". 
Innovation represents( an activity of creating a new product or service, new technologic process, new organization, or enhancement of existing product or service, existing technologic process and existing organization). According to the given definition, if we analyze its separate elements, we can say that we classify:

- innovations in production - development or enhancement of a specific product;

- innovations in services - offering new or enhancing of existing services;

- innovations in process - finding of new ways of organizing and combining inputs in the process of production of specific products or services;and innovations in management creating new ways of organizing business resourcesTan, (2004:2) mentioned that, any concept is liable to be abused if it is used loosely. The appropriate starting point of any definition is conceptual.

Innovation as a concept was first highlighted within academia by Joseph Alois Schumpeter, a Harvard economics professor, who saw innovation as a process that takes an invention and develops it all the way to a marketable product and service that changes the economy. Hana,(2013:83) stated tha,t the term "innovation" as such was used for the first time by Schumpeter at the beginning of the 20th century. His ideas and research have been developed by a number of other authors.

Schumpeter defined innovations as product, process and organizational changes that do not necessarily originate from new scientific discoveries (Žižlavský, 2011), but may arise from a combination of already existing technologies and their application in a new context (Žižlavský, 2011).

Innovation is a process of transforming the new ideas, new knowledge into new products and services. Joseph Schumpeter defines innovation as an activity which leads to new producing function, new product. He divides this activity in several steps, asFollows (McDaniel, 2002, p.57-58):

a) Introducing a new product: the entrepreneur should produce, namely introduce a new product which can be easily sold and which is not offered in the market;

b) Introducing a new method of production: innovation should offer a new scheme of production which through existing inputs can lead to an increased output, decrease of costs per unit product, introduction of new inputs and change of existing ones;

c) Opening new markets: innovations can increase the sell in new regions, and also increase the number of customers;

d) Finding of appropriate sources of raw materials: The raw material supplier can often lower raw materials' quality or increase their price and this directly influences over the quality and the selling price of the new product. Therefore, the entrepreneur should find an appropriate source of inputs, which are needed for production of newproducts;

e) Establishing a new organization in the industry: Schumpeter describes this step as an entrance of the entrepreneur in the monopoly market, where there has been no 
competition previously; or creating conditions through which the entrepreneur would take the monopoly position in the market(Hana,2013:38)

Tan,s (2004:2)added that ,Schumpeter's definition underlies another aspect of innovation - that of innovation as coming up with better products or what is broadly termed as product innovation. The problem with the conception of innovation as product innovation, in addition to its emphasis on technology and its associated $R \& D$, is that it is less relevant to the public service, traditionally associated with intangible products and more emphasis on services.Tan,S (2004:2) mentioned that ,what was needed is a conception of innovation as process innovation - emphasizing the creation of new value or new services for customers. Process innovation, however, suffers from vague conceptual boundaries. As John W. Hawks asked, where is the difference between innovation and:

- Doing something I know about more often

- Doing something I know about better

- Doing something somewhat different and

- Doing something altogether different. (Tan,S2004:2)

Michael Porter defined innovation:to include both improvements in technology and better methods or ways of doing things. It can be manifested in product changes,

- process changes,

- new approaches to marketing,

- new forms of distribution,

- and new concepts of scope ... [innovation] results as much from organizational learning as from formal R\&D.

This definition covers very similar points to Schumpeter's but indicates that innovation can stem from an organization's learning and not just the R\&D department. Innovation is about what's new and what's next. It's about that exciting leap forward into uncharted territory. Innovation is also about what works... better. It's about that incremental step forward that makes old ideas new again and repurposes the familiar into the unexpected.

Lionnet (2003, p. 6in Ramadan and Gerguri2011) defines innovation as a process by which a novel idea is brought to the stage where it eventually produces money. It is a dynamic technical,economic and social process involving the interaction of people coming from different horizons, with different perspectives and different motivations.UK Department of Trade andlndustry (2003, p.186in Ramadan and Gerguri2011) defines innovation as the successful exploitation of new ideas and it is central to meeting this challenge; it involves investments in new products, processes or services and in new ways of doing business.

"Successful innovation is the creation and implementation of new processes, products, services and methods of delivery which result in significant improvements in outcomes, efficiency, effectiveness or quality" (Albury 2005). Innovation is "the successful development,implementation and use of new or structurally improved products, processes, services or organisational forms" (Hartley, 2006). Innovation is "something new being realized with (hopefully) added value" (Jacobs and Snijders.2008). 


\section{ECONOMY AND INNOVATION :}

In daily conversation, terms like innovation, invention, creativity and science are often used interchangeably. But, for academics, researchers and policy Makers there are important distinctions between these terms and these distinctions give each term a unique, specific meaning. Invention is the first occurrence of an idea for a new product or process, while innovation is the first attempt to carry it out into practice (Fagerberg etal, 2004, p.4).

\section{Innovation and Entrepreneurship:}

The terms entrepreneurship and innovation are often used inter -changeably, but this is misleading. Innovation is often the basis on which an entrepreneurial business is built because of the competitive advantage it provides. On the other hand, the act of entrepreneurship is only one way of bringing an innovation to the marketplace. Technology entrepreneurs often choose to build a startup company around a technological innovation. This will provide financial and skill-based resources that will exploit the opportunity to develop and commercialize the innovation.Once the entrepreneur has established an organization, the focus shifts toward its sustainability, and the best way that this can be achieved is through organizational innovation. However, innovation can be brought to market by means other than entrepreneurial startups; it can also be exploited through established organizations and strategic alliances between organizations. Sullivan(2008:10)

Moreover, Innovation is the specific tool of entrepreneurs, the means by which they exploit change as an opportunity for a different business or service." (Drucker 1985).Ramadani and Geguri(2010:)stated that Innovation is essential for sustainable growth and economic development. Several core conditions enable innovation and encourage economic growth. In the modern economy, innovation is crucial for value creation, growth and employment and innovation processes take place at the enterprise, regional and national level.Innovation will lead to new businesses as well as to the increased competitiveness of existing enterprises

\section{Entrepreneur Education:}

Vicens and Grullón (2011:10) stated that ,entrepreneur education is critical for successful innovation. This section discusses the proposed methodology, the intended audiences, and the importance of introducing core knowledge to activate the innovation process, as well as the need to change the mindsets that can hinder the process. They add that, methodologically speaking, the program hinges on design thinking, case analysis and simulations, and active learning for developing the competencies required for the arduous task of starting a new business. Conceptually speaking, competencies are developed to understand the external business environment,assess the capabilities and resources of the entrepreneur and his team, and build and analyze business models for the new business, while using companies doing similar or opposite things as reference models (Mullins and Komisar, 2009). 


\section{What is entrper $\backslash$ Entrepreneurship Education:}

Ramanigopal,etal(2012:244)inroduced a clear definition to the term „they stated that ,entrepreneur" is derived from two French words "entre" and „prenure" meaning between and to take respectively. The word originally referred to those who would trade between the buyer and sellers o ", supply against demand" principle with its inherent risks and later it began to mean those starting a new venture [ barrigh and Ireland 2006, p5]The term Entrepreneurship has broadened and wider implication. It does not merely mean the ability to start some business. It may bring about a change in the mind set of people and can be a change in the social order. But it has a good spectrum of basic principles responsible for strong character, creativity innovation intelligence independence, productivity and the ability to avail of the prevalent opportunities on resources to great advantage.

The concept of entrepreneurship has been owned for several hundred years and has evolved greatly since its inception. It means much more than a mere reference to the commencement of a business enterprise, as vouchsafed by many economics while some economists hold the view that an entrepreneur is someone willing to take on the risk of starting a venture with the hope of profiting greatly, other believe that an entrepreneur is an innovator cashing is on their innovation.In the absence of an apt definition of entrepreneurship it can be taken to mean someone venturing out on their own on an opportunity holding the promise of making it big. Ramanigopal, et al (2012:244).

Economist Joseph Schumpeter calls entrepreneurship as a force fo creative destruction. He backs his theory with the argument that an entrepreneur take son new ideas and new combinations to help render ideas from the past obsolete. Ramanigopal, et al (2012:244).

Entrepreneurship education means many different things to educators -from primary schools to university, from vocational education to auniversity MBA. At each level of education, it is reasonable to expect_different outcomes as students mature and build on previous knowledge.But the overall purpose remains to develop expertise as an entrepreneur.

Based on the vision of original mentor, Professor Albert Shapiro atThe Ohio State University (deceased in 1985) the Consortium created theLifelong Learning Model to demonstrate that entrepreneurship is adevelopmental process. We recognize the importance of nurturing theentrepreneurial spirit from early ages, and continuing it right through alleducational levels. In most cases entrepreneurship is infused in classes where it provides the context for learning other basic skills and motivating students to want to learn. In the more advanced grades it also has become a separate course supporting the outcomes of the higher levels of the lifelong learning model.see figure 1 : 


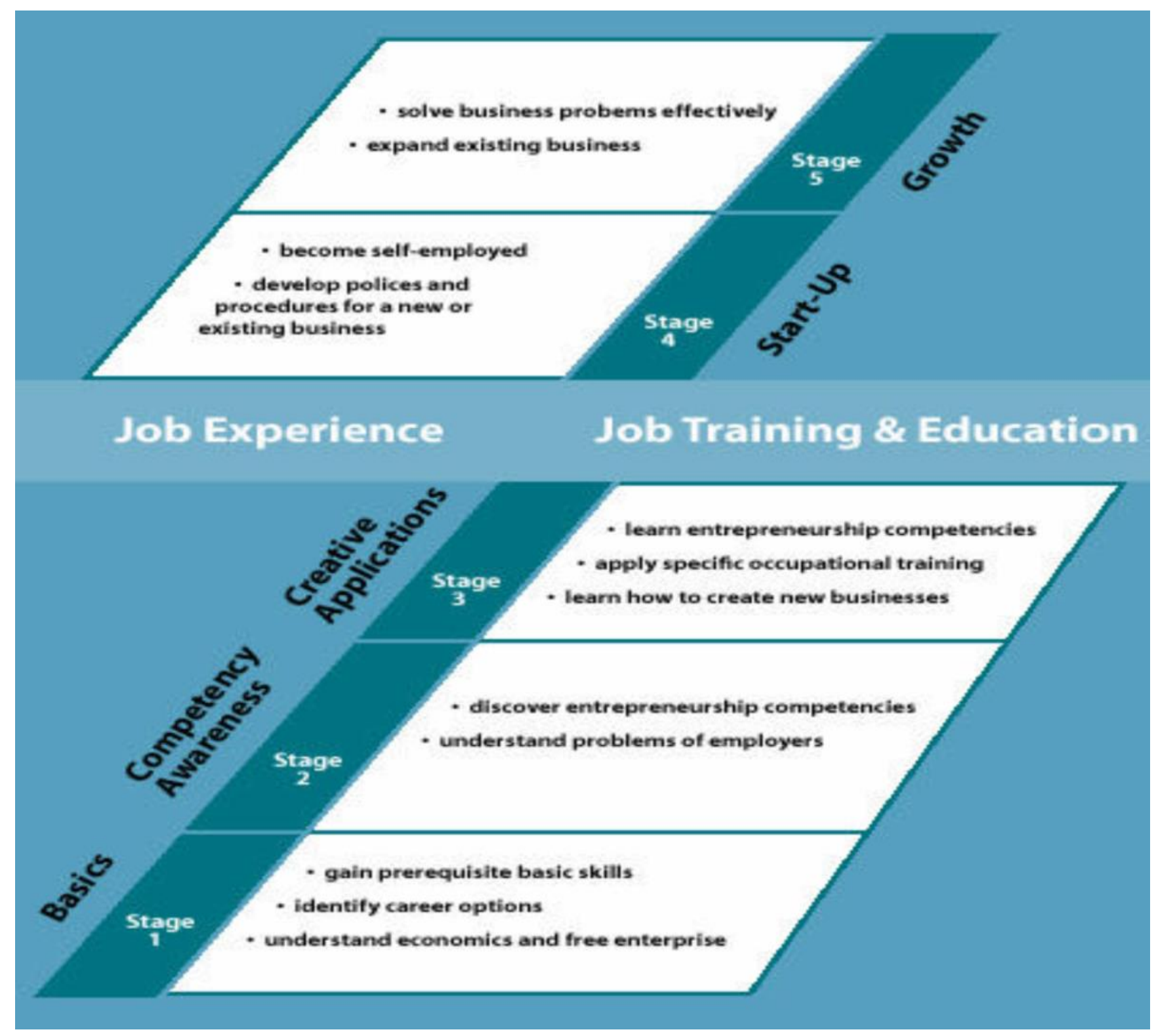

Figure1: Professor Albert Shapiro(1985), lifelong learning model adopted from the The Consortium for Entrepreneurship Education, Columbus, Ohio www.entre-ed.org

\section{Stage 1 - BASICS}

In primary grades, junior high and high school, students should experience various facets of business ownership. At this first stage the focus is on understanding the basics of our economy, the career opportunities that result, and the need to master basic skills to be successful in a free market economy. Motivation to learn and a sense of individual opportunity are the special outcomes at this stage of the lifelong learning model.

\section{Stage 2 - COMPETENCY AWARENESS}


The students will learn to speak the language of business, and see the problems from the small business owner's point of view. This is particularly needed in career and technical education. The emphasis is on beginning competencies that may be taught as an entire entrepreneurship class or included as part of other courses related to entrepreneurship. For example, cash flow problems could be used in a math class, and sales demonstrations could be part of a communications class.

\section{Stage 3 - CREATIVE APPLICATIONS}

There is so much to learn about starting and running a business it is not surprising that so many businesses have trouble. We expect future doctors to learn their profession through years of formal study, yet we have expected small business owners to learn everything by attending weekend seminars.

At this stage, students can take time to explore business ideas and a variety of ways to plan the business. Although, it is still only an educational experience, students must gain a greater depth and breadth of knowledge than they may have from previous stages. This stage encourages students to create a unique business idea and carry the decisionmaking process through a complete business plan. The best programs enable students to actually experience the operation of a business as well. This stage may take place in advanced high school career and technical programs, two-year colleges where there are special courses and/or associate degree programs, and some colleges and universities. The outcome is for students to learn how it might be possible to become an entrepreneur and to practice the processes of business.

\section{Stage 4 - STARTUP}

After adults have had time to gain job experience and/or further their education, many are in need of special assistance to assemble a business idea. Community education programs focusing on business startup assistance are widely available in career and technical programs, community-based assistance programs, community colleges, 4 year colleges and universities. The U.S. Small Business Administration sponsors many of these training programs.

\section{Stage 5 - GROWTH}

Often, business owners do not seek help until it is almost too late. A series of continuing seminars or support groups can assist the entrepreneur in recognizing potential problems and how to deal with them in a thorough and timely manner. Many community colleges and continuing education programs at universities or colleges offer such seminars and workshops for their business community. They recognize that the best economic development plan is to help the community's existing businesses grow and prosper. Educators at each of these stages of entrepreneurship should focus on their own special outcomes, and reach out for partnerships with educators at other levels of this lifelong learning process. There is room for entrepreneurship in some way everywhere in our educational system

\section{P21 Framework- 21st Century Learning.:}


The Partnership for 21st Century Skills has developed a vision for student success in the new global economy. see figure 2

\section{Figure -2:-21st century students outcome}

\section{1st Century Student Outcomes and Support Systems}

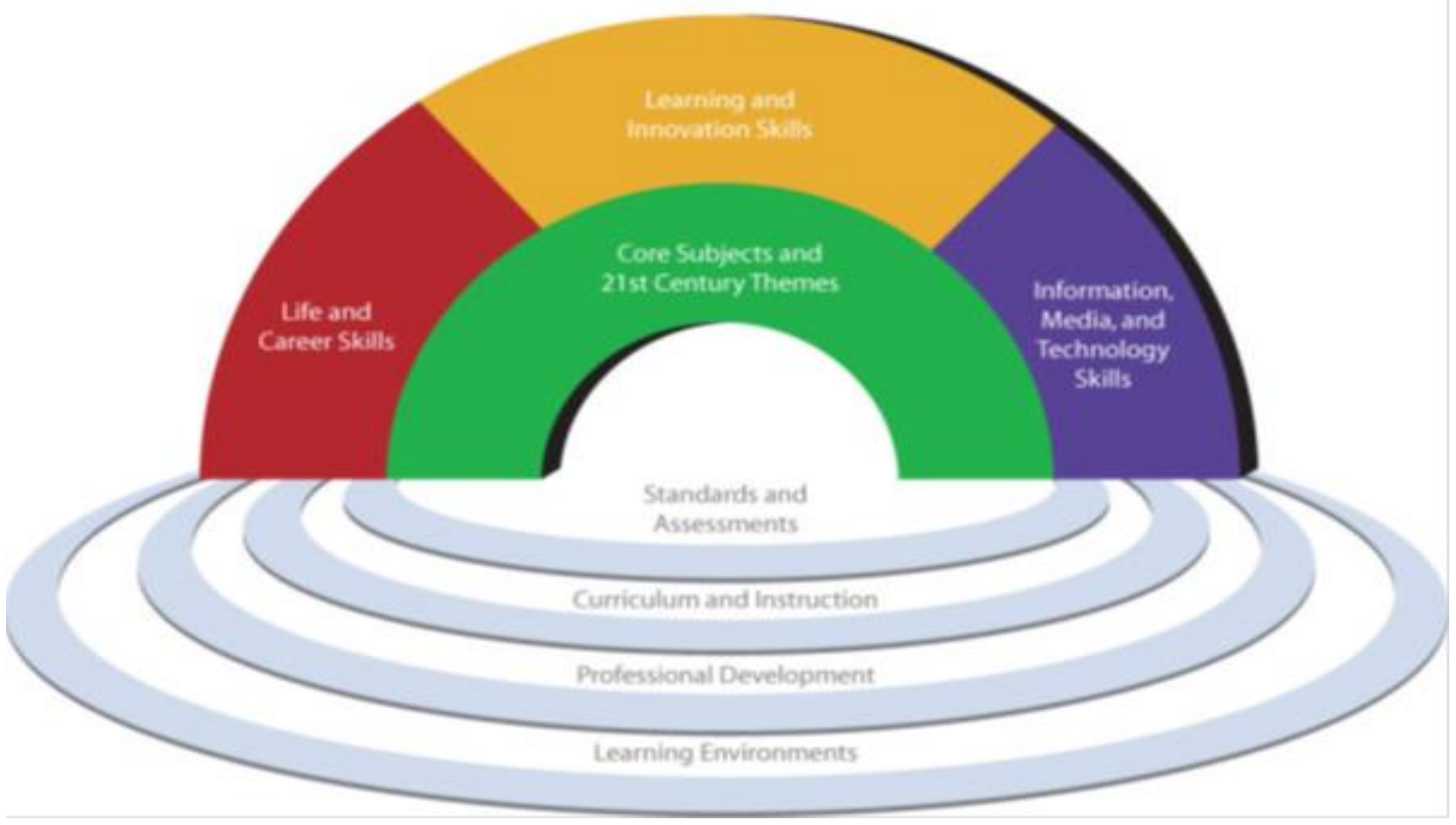

Adopted from http://www.p21.org/storage/documents/1. p21 framework 2-pager.pdf

\section{$21^{\text {st }}$ C E N T URY S T U DE N T O U T C O MES:}

To help practitioners integrate skills into the teaching of core academic subjects, the Partnership has developed a unified, collective vision for learning known as the Framework for 21st Century Learning. This Framework describes the skills, knowledge and expertise students must master to succeed in work and life; it is a blend of content knowledge, specific skills, expertise and literacies.

Every 21st century skills implementation requires the development of core academic subject knowledge and understanding among all students. Those who can think critically 
and communicate effectively must build on a base of core academic subject knowledge. Within the context of core knowledge instruction, students must also learn the essential skills for success in today's world, such as critical thinking, problem solving, communication and collaboration.

When a school or district builds on this foundation, combining the entire Framework with the necessary support systems-standards, assessments, curriculum and instruction, professional development and learning environments-students are more engaged in the learning process and

graduate better prepared to thrive in today's global economy

\section{Core Subjects and 21st Century Themes}

Mastery of core subjects and 21st century themes is essential to student success. Core subjects include English, reading or language arts, world languages, arts, mathematics, economics, science, geography, history, government and civics. In addition, schools must promote an understanding of academic content at much higher levels by weaving

\section{1st century interdisciplinary themes into core subjects:}

- Global Awareness

- Financial, Economic, Business and Entrepreneurial Literacy

- Civic Literacy

- Health Literacy

- Environmental Literacy

\section{Learning and Innovation Skills}

Learning and innovation skills are what separate students who are prepared for increasingly complex life ,and work environments in today's world and those who are not. They include:

- Creativity and Innovation

- Critical Thinking and Problem Solving

- Communication and Collaboration

\section{Information, Media and Technology Skills}

Today, we live in a technology and media-driven environment, marked by access to an abundance of information, rapid changes in technology tools and the ability to collaborate 
and make individual contributions on an unprecedented scale. Effective citizens and workers must be able to exhibit a range of functional and critical thinking skills, such as:

- Information Literacy

- Media Literacy

- ICT (Information, Communications and Technology) Literacy

\section{Life and Career Skills}

Today's life and work environments require far more than thinking skills and content knowledge. The ability to navigate the complex life and work environments in the globally competitive information age requires

students to pay rigorous attention to developing adequate life and career skills, such as:

- Flexibility and Adaptability

- Initiative and Self-Direction

- Social and Cross-Cultural Skills

- Productivity and Accountability

- Leadership and Responsibility

$21^{\text {st }}$ century skills :

The Partnership for 21st Century Skills has developed a vision for student success in the new global economy. These skills are Adapted from Partnership for 21st Century Skills. (2009). P21 Framework Definitions. Retrieved January 3, 2011 from http://www.p21.org/documents/P21 Framework Definitions.pdf

\section{Creativity \& Innovation :}

Students will :

Cultivate creative thinking both independently and in groups through brainstorming and other idea generating strategies

Develop, communicate and implement original, inventive ideas (both big and small, incremental and radical)

Be open to risk-taking, failure, feedback from others, and diverse perspectives, and

Analyze, evaluate, and refine their ideas

\section{Critical Thinking \& Problem Solving}

Students will 
Use inductive and deductive reasoning as well as system thinking to solve problems

Analyze, synthesize, and interpret evidence to form decisions and reflect on learning

Evaluate facts, ideas, claims, and beliefs

Analyze alternative points of view

Critically reflect on learning and ask questions

Students will

Communicate clearly and for many purposes (e.g. persuade, instruct, inform, and motivate) through speaking, writing, and non-verbal cues in many contexts and multi-cultural/multi-lingual situations

Listen effectively for understanding

Use multiple media technologies best suited for the message \& audience

Collaborate with others, share responsibility, and be flexible, adaptable, and respectful of others

\section{Information, Media, and Technology Skills:}

Information Literacy

Students will :

Efficiently and effectively access information

* Critically evaluate, accurately use, and creatively apply information to problemsolving

Manage information from a wide array of sources

Demonstrate ethical behavior and knowledge of legal issues surrounding information, such as intellectual property and citation of sources.

\section{Media Literacy}

Students will

Analyze media messages to illuminate purpose

* Construct media messages and use media tools to create messages appropriate to particular audiences

* Understand how different points of view and cultural/linguistic backgrounds impact media communications and how media informs beliefs

* Practice ethical behavior and awareness of legal issues surrounding media, such as fair use, copyright and licensing

\section{Information, Communications and Technology Literacy}

Students will :

Demonstrate use of technology as a tool for research

Utilize digital devices, software, and networking tools to search, organize and evaluate information 
Use social networks and other channels to communicate information appropriately Demonstrate ethical, legal and respectful behavior while using information technology

Life \& Career Skills:

\section{Flexibility \& Adaptability}

Students will :

Be flexible and able to work with individuals of various cultural/linguistic backgrounds and those who have differing points of view

Adapt to changes in priorities, timelines, roles, and duties

Manage self and tasks in a climate of ambiguity

Effectively incorporate feedback, including praise and criticism

\section{Initiative \& Self-Direction}

Students will :

Self-direct and self-manage learning, prioritize tasks, and use time wisely

Take initiative for advancing own knowledge and skill set

Set both tactical and strategic goals

Practice personal reflection and meta-cognition to set and achieve future goals

Commit to life-long learning

\section{School \& Cross-Cultural Skills}

Students will

- Be open-minded and encourage and apply diversity of opinions to create new ideas

- Respect individuals from varying cultural, linguistic, social, and economic backgrounds

- Work and interact effectively with diverse teams

- Engage in professional and respectful conduct and behavior including knowing when to speak and when to listen

\section{Productivity \& Accountability}

Students will

Manage projects effectively to achieve intentional results

Set goals despite obstacles

Be accountable for tasks, roles, and duties

Work respectfully and collaborate with others

Produce high-quality results

\section{Leadership \& Responsibility}

Students will 
Build rapport and trust with peers by demonstrating integrity and ethical behaviors

Negotiate, collaborate and inspire others to accomplish shared goals

Utilize personal strengths and strengths of others in collaborative work

Act responsibly

Lead others through use of interpersonal \& problem-solving skills

Developing cultural competence in working with others by recognizing and respecting cultural differences and work with others from a wide range of cultural and social backgrounds

\section{How Should Instruction Change to Prepare Students for Success in the 21st Century?}

The 21st century skills are not really different. We have always wanted students to be creative thinkers and problem solvers who have the skills necessary to function effectively in society and in the workplace. However, the way in which these skills are incorporated in the classroom and how technology is integrated will greatly change instruction. Indeed, with technology, today's classroom transcends physical walls and reaches around the globe. In addition, we need to plan instruction with an understanding of the "digital natives" (Prensky, 2001) who have grown up in the Digital Age and who expect learning to be interactive, engaging and up-to-date. Beers(2011:4)

Beers(2011:4) stated some Instruction that meets the needs of today's students will incorporate as :

A variety of learning opportunities and activities

The use of appropriate technology tools to accomplish learning goals

Project- and problem-based learning

Cross-curricular connections

A focus on inquiry and the student-led investigations

Collaborative learning environments, both within and beyond the classroom

High levels of visualization and the use of visuals to increase understanding

* Frequent, formative assessments including the use of self-assessment

\section{Importance of Innovation and Entrepreneurship}

Entrepreneurship education has gone from teaching how to prepare a business plan to focusing on the development of a way of thinking and acting, as well as on the process involving ideation, creating a business, and managing its growth, as exemplified by Babson's programs. Mullins and Komisar (2009)argue that the process of jumpstarting a new business is hampered by misconceived business plans based on unproven suppositions and rigid business models. They suggest that the success of companieslike Google, PayPal, and Starbucks required making radical changes to their original business plans and they propose a process for testing the initial idea and using the information obtained during the jumpstart phase to make corrections to the business model, allowing the company to achieve positive result.

The entrepreneur education process must incorporate public policymakers since they should be aware of the importance and potential of education in developing innovation 
and entrepreneurship capabilities and the impact on society. Furthermore, they must understand the impact that their decisions have on this process.. In many countries, numerous Internet sites, blogs, magazines, and radio or television programs address the subject of innovation and entrepreneurship; however, all of these individual efforts could have a larger impact if they were connected in one big digital community. The promotion of an entrepreneurial culture is often pushed into the background. In other cases, it is understood that the mere existence of magazines and television programs covering the subject are sufficient. The quality of the material being prepared or disseminated is critical to educate audiences and achieve an adequate understanding of the reasons for the success or failure of businesses Education should not stop at the university or community classroom; it should be open, continuous, and permanent by means of the massive diffusion of business cases. The importance of entrepreneurship and innovation for the development of the region's countries requires the unleashing of an epidemic that will spread the entrepreneurial virus to everyone.

Furthermore, there are different benefits for students in different levels all are adopted from "The Consortium for Entrepreneurship Education, Columbus, Ohio "http://www.entre-ed.org/

This web page is for teachers, instructors, youth leaders, program developers and others who help students of all ages find their own entrepreneurial opportunities.

\section{Benefits to Elementary Students:}

Increased attendance

Higher academic achievement

Standardized Tests

Pre \& Post Tests

Portfolio

Fewer discipline referrals

Increased sense of "locus of control"

Awareness of career and entrepreneurial options

Acquire basic economic understanding

Acquire basic financial concepts

Define entrepreneurs' contribution to society

Use opportunity recognition/ problem solving skills

Explore ethics issues

Consider steps in business startup

\section{Benefits to Middle School Students}

- Continue on to high school

Improved academic skills - 4 Rs

- Experience entrepreneurship across the curriculum

- Increased self-esteem and respect

- Increased number of students identifying entrepreneurship as a career choice

- Heightened awareness of the role of entrepreneurs

- Encourage risk-taking \& learning from failure 
- Learn to identify and recognize opportunities

Decrease in teen pregnancies and substance abuse

Improved economic literacy and understanding of capitalism

Improved financial literacy

Develop workplace literacy

Understand entrepreneurship process/ business plan

Become an educated, empowered consumer

Learn about opportunity cost

Embrace diversity/ socialization skills

Demonstrate conflict resolution/ negotiation/ sales-marketing/

persuasion skills

Learn how entrepreneurs give back

Learn how to make money

Recognize the contributions of entrepreneurs (they started small)

Foster and value idea generation

\section{Benefits to High School Students}

Creation of entrepreneurial thinkers who also have the skills and tools to start their own businesses.

Write a business plan

Apply economic principles

Determine individual entrepreneurial interests

Apply basic marketing skills

Use strategies for idea generation

Assess feasibility of ideas

Manage risk

Identify legitimate sources of capital

Evaluate ownership structures

Translate problems into opportunities

Apply principles of human relations management

Speak "business" \& "entrepreneurship"

Apply basic accounting principles

Engage in ethical business practices

Demonstrate financial management

\section{Benefits to Post-Secondary and Adult Students}

Demonstrate skills in business startup

Demonstrate skills in maintaining business longevity

Demonstrate knowledge of business closings versus failure

Ability to find next level of training or access other resources and services

Demonstrate business management/ operation skills

Use components of a business plan

Determine impact on unemployment 
Changed attitude toward entrepreneurship as a means of making a living

Changes in personal and career attitudes including

Self-worth

Ability to control one's own life

Self awareness

Self management/ personality responsibility

Transfer of learning

Motivation

Teamwork

Interpersonal communications

Problem solving

Creativity

\section{$21^{\text {st }}$ century standards:}

Before illustrating the content Standards for Entrepreneurship Education it is important to clarify the $21^{\text {st }}$ century standards in general which is adopted from this website: http://www.p21.org/about-us/p21-framework/351-21st-century-standards

- Focuses on 21st century skills, content knowledge and expertise.

- Builds understanding across and among core subjects as well as 21st century interdisciplinary themes

- Emphasizes deep understanding rather than shallow knowledge

- Engages students with the real world data, tools, and experts they will -encounter in college, on the job, and in life--students learn best when actively -engaged in solving meaningful problems

- Allows for multiple measures of mastery

\section{The Content Standards for Entrepreneurship Education:}

In the following table in this website . www.entre-ed.org, there are a summary of the Content Standards for Entrepreneurship Education.and for more details see The Consortium for Entrepreneurship Education, Columbus, Ohio website . www.entre-ed.org

\section{Recommendations and Suggestions:}

- It is clear that there is a need to spread the culture of innovation and Entrepreneurship in all the education systems .

- more researches are recommended to identify the concepts of innovation and Entrepreneurship.

- More efforts should be given to integrate the $21^{\text {st }}$ century learning outcomes with the curricula . 
- More efforts should be given to the implementation of $21^{\text {st }}$ century skills and practices in our curricula.

- provide schools and universities with the knowledge, abilities, and skills required for successful entrepreneurship and to participate in the innovation and business

- introduce the technology and market knowledge needed to accelerate innovation and entrepreneurship

- improve the competitiveness of clusters and promote entrepreneurship and innovation.

- Entrepreneurship and innovation also should address the lifelong learning process, as well as critical links between primary, secondary, higher and vocational education

\section{References:}

Beers,s (2011), 21st Century Skills: Preparing Students for THEIR Future. https://www.mheonline.com/mhmymath/pdf/21st_century_skills.pdf

Hana,U,(2013) Competitive Advantage Achievement through Innovation and Knowledge, Competitiveness vol5,issue $1 \mathrm{http}: / /$ www.cjournal.cz/files/127.pdf

Lorenzo Vicens and Sergio Grullón, (2011),Innovation and Entrepreneurship . the Fifth Americas Competiveness Forum for the Inter-American Development Bank and Compete Caribbean October $5-7,2011$

Ramadani ,and Gerguri(2010),Innovation: Principles and Strategies,South-East European University at Tetovo

Sullivan(2008).innovation . http://www.sagepub.com/upm-data/23137_Chapter_1.pdf

MASSIVENESS RAMANIGOPAL,c,PALANIAPPAN,G,and HEMALATHA,n (2012), NEED FOR ENTREPR.ENEURSHIP EDUCATION IN

SCHOOL STUDENTS, International Journal of Physical and Social Sciencesvol,2 issue,3 http://www.ijmra.us

Tan,B(2004). The Consequences of Innovation .The Innovation Journal: The Public Sector Innovation Journal, Volume 9 (3).

The Consortium for Entrepreneurship Education, Columbus, Ohio(2004). www.entre-ed.org http://www.entreed.org/Standards_Toolkit/standards_summary.htm

2007, June. "Apple - ACOT2 - Understanding of 21st Century Skills and Outcomes." Understanding of 21st Century Skills and Outcomes. Apple, 2008. Web. 30 Mar. 2011. http://ali.apple.com/acot2/skills/

"P21 Framework Definitions." Partnership for 21st Century Skills, Dec. 2009.Web.20Mar.2011.http://www.p21.org/documents/P21_Framework_Definitions.pdf

Partnership for 21st Century Skills. (2009). P21 Framework Definitions. Retrieved January 3, 2011 from http://www.p21.org/documents/P21_Framework_Definitions.pdf 